\title{
AGE DYNAMICS OF YOUNG RABBITS MEAT QUALITY
}

Aksenov E. A., Vakulenko I. S., Institute of Animal Science of the NAAS

Rabbit breeding is one of the most profitable branches of animal husbandry, which plays a significant role in food and fur products human providing.

The rabbit breeding industry goal is a fur, down and meat production.

Rabbit meat, as a dietary product, is used in the diet of people of any age. It is juicy, low-fat, with a significant amount of full value protein and very small cholesterol, finely fibrous, highly digestible and has no contraindications for use at various diseases.

Adverse environmental changes were necessitated the use in rabbits feeding of environmentally friendly mineral components and natural minerals, the consumption rates determination and their introduction into the diet.

The article presents the results of 30 - 150 days old meat-fur rabbits chemical (moisture, dry matter), physical-technological (water-holding capacity, spot area, acidity) characteristic of meat and longest back muscle determination at the combined type of feeding, as well as its caloric and biological value. It that The biological value of rabbits meat conditionality from the high protein content was established. In addition, the rabbits meat productivity depends on their age. At the same time, the optimum terms of rabbits slaughter were established.

Key words: biological value of meat, calorie content, combined type of feeding, rabbits, longest back muscle, physical and technological properties, chemical composition.

DOI 10.32900/2312-8402-2018-120-29-39

УДК 636.596.082(044)

\section{СУЧАСНИЙ СТАН ТА ПЕРСПЕКТИВИ РОЗВИТКУ М'ЯСНОГО ГОЛУБІВНИЦТВА В УКРАЇНІ (ОГЛЯДОВА)}

\author{
Вінюков А. О., асп. ${ }^{2}$ \\ Інститут тваринництва НААН \\ Вінюков О. О.
}

Донецька державна сільськогосподарська дослідна станція НААН

В статті розглянуті питання визначення перспектив розвитку такого нішового сектору агробізнесу, як м'ясне голубівництво. Проведено літературний та патентний пошук з метою встановлення стану галузі м'ясного голубівництва в Украйні. Вивчено закордонний досвід в галузі м'ясного птахівництва. Визначено, щзо в багатьох країнах світу промислове голубівництво дуже розвинуте. На великих голубиних фермах США і державних фермах Угорщини прочеси годівлі, напування, збирання приміщень механізовані, освоєно штучне вигодовування пташенят. Спочатку для селекиійної роботи Угорське товариство голубівників закупило племінне поголів'я у Франиії, а також використовувало свої національні породи великих голубів. В даний час ведеться планомірна робота по створенню гібридів великої живої маси, плідних, невибагливих і стійких до захворювань.

\footnotetext{
${ }^{2}$ Науковий керівник-д. с.-г. н., доцент Церенюк О. М.
} 
Розглянуто окремі елементи технології виробництва продукиії голубівниитвва. Відмічено певні особливості галузі. Парування у голубів починається $з$ n'ятимісячного віку. Молодняк голубів м'ясних порід, виведений в березні $i$ залишений на плем'я, у вересні-жовтні вже дає приплід. В середньому у однієї пари м'ясних голубів при інтенсивній технології за рік може бути 9-10 кладок. Вихід товарної продукиії складе 8,5-9,0 кг протягом року. Виробництво товарної продукиії, як правило, нерівномірне: 60-65\% м'яса отримують у весняно-літній період, 20-30 \% - восени і 10-15\% взимку. На сьогоднішній день виробництво рентабельне, якщо виведення молодняку в господарстві становить не менше $75 \%$. У перші роки життя репродуктивна здатність у голубів поступово підвищується, потім рівномірно знижується і на 6-7-му рочі різко падає. Взагалі ж голуби живуть в середньому 15-20 років, а розмножуються протягом 10-12 років.

Голуби моногамні, тримаються зграями $і$ ведуть денний спосіб життя. Насиджують яйия обидві птииі: самеџь зазвичай з 10 до 16 години, самка весь інший час. Маса яєць у голубів коливається від 17 до 27 г. Температура насиджування яєць становить $36,1-40,7^{\circ} \mathrm{C}$. Тривалість насиджування у домашнього голуба в середньому 17-19 діб, але в холодному приміщенні збільшується до 20-22 днів.

Ключові слова: птахівництво, голуби, продуктивність, м'ясні породи, дієтичне м'ясо, ринок продукції.

Окрім забезпечення населення країни повноцінним високоякісним білком тваринного походження є також важливий напрямок - виробництво достатньої кількості дієтичного м'яса. В останні роки цей напрямок отримує особливу важливість із-за зростання потреби в дієтичному харчуванні при реабілітації важкохворих людей. Також, Б. В. Болтянський та ін., 2018, зазначають, що останнім часом в Україні існує тенденція боротьби з зайвою вагою. У зв'язку з цим частина українців вдається до дієтичного харчування, що стимулює розвиток ринку дієтичних продуктів харчування [1]. Наявність зміни у погляді на дієтичне харчування на вітчизняному ринку в останні роки підкреслює ціла низка науковців [1-3]. Про тренд у бік виробництва більш корисної та здорової продукції за виробництва по різних видах сільськогосподарських тварин та птиці наголошують як вітчизняні так і закордонні науковці [4-8].

Отже, потреба в дієтичних продуктах на вітчизняному ринку є і в подальшому буде тільки зростати. При цьому, одним з потенційних напрямів для нарощування обсягів виробництва дієтичного м'яса є м'ясне голубівництво. Цей напрямок птахівництва в Україні розвинуто недостатньо, хоча в деяких країнах наявне промислове виробництво продукції голубівництва.

Отже, враховуючи вищезазначене, в якості мети досліджень нами обрано визначення перспектив розвитку такого нішового сектору агробізнесу, як м'ясне голубівництво.

Матеріал і методи досліджень. Було проведено літературний та патентний пошук з метою встановлення стану галузі м'ясного голубівництва в Україні. Вивчено закордонний досвід в галузі м'ясного птахівництва.

Результати досліджень. Голуби, як і інші птахи, споживалися людиною 3 доісторичних часів. Ще в I в. до н. е., страви з голубиного м'яса вважалися делікатесом і подавали до столу імператорів. Авіценна вважав м'ясо голубів лікувальним. За поживністю і смаковими якостями воно перевершує м'ясо курей, качок i гусей. У ньому міститься 20 \% білка і 9 - 20 \% жиру. При цьому найсмачніше i ніжне м'ясо отримують від м'ясних порід голубів. У середні віки вирощування голубів на м'ясо вважалося звичайною справою в багатьох країнах Свропи, а 
страви з голуб'ятини можна було побачити, як на столі у аристократа так і у простого селянина [9].

У світі налічується близько 50 порід м'ясних голубів. Їх поділяють на три групи: велетенські (голуби-велетні), курячі та м’ясні [10].

Велетенські - великі, важкі, кремезні, літають погано. Серед них відомі породи: кінг, техаський, карно, кошуа, монден (мондайн, мондаин), монтобан, римський, соттобанка, угорський велетень, итрассер.

Характерні особливості групи курячих (вони дуже схожі на курей) - це короткий широкий тулуб, довгі ноги і шия, короткий хвіст. Ці голуби великовагові і плідні. Група включає наступні породи голубів: флорентійський, угорський, мальтійський, віденський.

M'ясні породи голубів, на відміну від перших двох груп, дуже схожі зі звичайними домашніми голубами, але дещо крупніше, маса тіла досягає в середньому 600 г. До цієї групи відносяться: польська рись, бенешовський голуб, прахенськийканик, моравський пштрос, кобурзький жайворонок.

Розкриття корисних властивостей голубиного м'яса для населення в сучасних умовах та розвиток м'ясного промислового голубівництва в Україні $є$ актуальним, особливо для малого та середнього бізнесу.

При цьому, слід враховувати те, що між різними породами м'ясних голубів наявні й різниці за обсягами, основними характеристиками та якістю м'ясної продукції [11-14].

В багатьох країнах світу промислове голубівництво дуже розвинуте. На великих голубиних фермах США і державних фермах Угорщини процеси годівлі, напування, збирання приміщень механізовані, освоєно штучне вигодовування пташенят. Спочатку для селекційної роботи Угорське товариство голубівників закупило племінне поголів'я у Франції, а також використовувало свої національні породи великих голубів. Потім в США були придбані аутентичні птахи породи тексан, і в даний час ведеться планомірна робота по створенню гібридів великої живої маси, плідних, невибагливих і стійких до захворювань [15]. Розведення м'ясних голубів набуло широкого поширення і в Німеччини, Чехії та Словаччині [16-17].

На сучасному етапі м'ясне голубівництво в Україні широкого поширення не отримало. Одна з причин цього - страх людей до не відомого, невідрегульований внутрішній ринок, а також слабка обізнаність населення щодо корисності голубиного м'яса. Поголів'я м'ясних голубів зустрічається в незначних кількостях в приватних колекціях та приватних розплідниках. Кількість такого поголів'я не дозволяє навіть думати про реалізацію м'яса цих птиць [18].

В кінці 70-х років в Одеській області були створені експериментальні голубині ферми при колгоспах «Більшовик» та ім. Дзержинського. На цих підприємствах дуже ефективно розвивався цей напрямок птахівництва, але слабка конкурентна здатність цієї продукції, а також розпад СРСР призвели до занепаду цих підприємств [19].

Останнім часом, інтерес до м'ясного голубівництва починає зростати. Багато фахівців відзначають великі можливості України для розвитку м'ясного голубівництва: наявність значних вільних трудових ресурсів, необмежена кормова база, швидко зростаючий ринок пташиного м'яса і зокрема - делікатесних м'ясних продуктів. Однак, більшості птахівників, розведення м'ясних голубів залишається предметом малознайомим.

Деякі технологічні аспекти виробництва продукції м'ясного голубівництва. Парування у голубів починається з п'ятимісячного віку. Молодняк голубів 
м'ясних порід, виведений в березні і залишений на плем'я, у вересні-жовтні вже дає приплід. В середньому у однієї пари м'ясних голубів при інтенсивній технології за рік може бути 9-10 кладок (18 пташенят). Отже, очікуваний вихід товарної продукції складе 8,5-9 кг протягом року. Виробництво товарної продукції, як правило, нерівномірне: 60-65 \% м'яса отримують у весняно-літній період, 20-30 \% восени і 10-15 \% взимку. Виробництво може бути рентабельним, якщо виведення молодняку в господарстві становить не менше 75 \%. У перші роки життя репродуктивна здатність у голубів поступово підвищується, потім рівномірно знижується і на 6-7-му році різко падає. Взагалі ж голуби живуть в середньому 1520 років, а розмножуються протягом 10-12 років.

Голуби моногамні, тримаються зграями і ведуть денний спосіб життя. Насиджують яйця обидві птиці: самець зазвичай з 10 до 16 годин, самка весь інший час. Маса яєць у голубів коливається від 17 до 27 г. Температура насиджування яєць становить $36,1-40,7{ }^{\circ} \mathrm{C}$. Тривалість насиджування у домашнього голуба в середньому 17-19 доби, але в холодному приміщенні збільшується до 20-22 днів.

Відразу після вилуплення голуб'ята абсолютно сліпі і покриті пухом, вони вимагають регулярного годування і обігріву батьками. Голуби годують пташенят з дзьоба в дзьоб зобним молочком протягом 10-12 діб, потім поступово включають в їх раціон розм'якшені в зобу зерна. На 6-8 добу пташенята починають відкривати очі, а в місячному віці переходять на повне самообслуговування.

Голубине зобне молочко - дуже поживна кормова маса жовто-білого кольору, консистенції рідкої сметани. Голубине молоко виділяється епітелієм стінок зоба дорослих голубів. На відміну від ссавців у голубів ця речовина виділяють не тільки самки, але і самці. У складі голубиного молочка 64-82 \% води, 10-19 \% білка, 7-13 \% жиру і жироподібних речовин, 1,6 \% - мінеральних речовин і вітамінів A, D, E i B.

За комфортні умови інтенсивність росту голуб'ят виключно висока. Так, жива маса в перші два дні збільшується в 8-10 разів, з 11 до 22 днів - у 2 рази і потім стабілізується, а перед вильотом 3 гнізда навіть знижується. У 60-70денному віці пташенята досягають живої маси дорослих птахів [14-16].

Голуб'ят забивають на м'ясо, коли вони ще не літають - у віці 28-30 днів. До цього часу голуб'ята вже мають досить високу живу масу. При більш пізньому забої смакові якості м'яса погіршуються, воно стає жорстким. Для додання м'ясу делікатесних властивостей і смаку дичини, за кілька днів до забою в корм голубів додають насіння анісу, кмину або кропу, поять їх підсоленим молоком.

Інтенсивний спосіб розведення застосовується на товарних підприємствах, що здійснюють вирощування голубів на м'ясо для реалізації на внутрішньому ринку. При цьому використовуються спеціалізовані м'ясні породи голубів і гібриди, що мають живу масу 850-1500 г, при відгодівлі на м'ясо досягають до 4-5тижневого віку живої маси 600-800 г. Утримують голубів у спеціальних пташниках, в яких виділяється приміщення для утримання батьківського стада, приміщення для молодняку і підсобні приміщення для зберігання кормів, підстилки, інвентарю. Приміщення розділяється перегородками на секції-бокси, кількість яких залежить від чисельності маточного стада. В одному боксі зазвичай містять 10-15 пар. Кожен бокс ділиться металевою сіткою на дві секції, в яких встановлюють 2-5-ярусні клітинні батареї, по 24-40 осередків-гнізд в кожній. Щільність посадки м'ясних голубів в приміщенні - 2-3 пари на 1 м² площі підлоги приміщення. На кожну птицю в пташнику повинно припадати не менше $1 \mathrm{~m}^{3}$ обсягу приміщення. Фронт годування 5-6 см / гол. Зовні біля кожної секції прилаштову- 
ються вольєри з розрахунку $0,5 \mathrm{~m}^{2}$ площі вольєри на кожну пару голубів. У вольєр голуби потрапляють через лази.

Годівля м'ясних голубів. Як і інших видів птахів, годівля м'ясних голубів має бути біологічно повноцінним, задовольняти їх потребу птиці в енергії, поживних і біологічно активних речовинах для здійснення нормальної життєдіяльності організму, росту молодняку і продукування дорослої птиці.

Основними кормами і кормовими інгредієнтами для голубів $є$ зернові корми (кукурудза, ячмінь, овес, просо, пшениця, рис, сорго); зернобобові корми (горох, соя, люпин), насіння олійних культур (соняшнику, ріпаку, суріпиці, льону, конопель, анісу, кропу), білкові корми рослинного походження (макухи та шроти, кормові дріжджі пекарські і), тваринного походження (м'ясо-кісткове і рибне борошно); мінеральні корми (крейда, черепашка, вапняк, монокальційфосфат, дикальцийфосфат, кісткове борошно, шкаралупа яєць, кухонна сіль), вітаміни і мікроелементи.

В енциклопедії з птахівництва відзначається, що в 100 г суміші для дорослих голубів має міститися 15 \% перетравного протеїну, 110-115 кормових одиниць і 3 \% клітковини [15].

Ринок дієтичного м'яса. М'ясо голубів є найважливішим джерелом повноцінного білка і ліпідів з високим рівнем незамінних жирних кислот. Воно характеризується високою харчовою і біологічною цінністю, яка визначається наступними факторами: змістом незамінних амінокислот, їх оптимальним співвідношенням що сприяє доброму травленню ферментами шлунково-кишкового тракту.

Голуб'ятина багата водорозчинними вітамінами, а також A, D, E, які містяться в ліпідній частині, крім того, макроелементами, серед яких виділяються за кількістю калій, фосфор, натрій, кальцій та інші, а також деякі мікроелементи, які мають істотне значення в обміні речовин.

Продукція голубівництва відноситься до найбільш якісних в дієтичному відношенні продуктів харчування, чим і пояснюється великий інтерес до розведення даного виду сільськогосподарської птиці за кордоном.

В той же час, С. Л. Войтенко та О. О. Власенко, 2018, зазначають, що на початку 2018 року генофонд птиці в суб'єктах племінної справи був представлений такими видами: кури, качки, гуси, індики, перепела і страуси. Відносно виробництва товарної продукції, слід відмітити, що в Україні спостерігається чітка тенденція до збільшення споживання м'яса птиці на душу населення порівняно 3 аналогічним показником для інших видів м'яса. Зокрема, споживання м'яса птиці на душу населення протягом 2006-2016 pр. збільшилося від 15,7 кг до 24 кг. Споживання цього виду м'яса зростає випереджальними темпами порівняно із іншими видами [21]. За січень-жовтень 2016 року в Україні було вироблено 1846,7 тис. тонн м'яса всіх видів (у забійній вазі) всіма категоріями господарств. в тому числі сільськогосподарськими підприємствами - 1236,8 тис. тонн [22]. В той же час, асортимент м'ясної продукції невеликий: понад 90 \% з цієї кількості становить м’ясо бройлерів і курей, інше - м'ясо водоплавної птиці та індиків.

Виробництво м'яса інших видів птахів незначне і становить в кращому випадку соті частки одного відсотка. У той же час поява класу заможних людей призвело до значного зростання попиту на високоякісну і екзотичну м'ясну продукцію, таку, наприклад, як м'ясо страусів, фазанів, цесарок, перепелів, голубів, велику жирну печінку водоплавної птиці. Велика частина подібної продукції в даний час імпортується, на що витрачаються значні валютні кошти. Крім того, необхідність перетину багатьох кордонів подовжує шлях продукції до споживача, що призводить до зниження iї якісних показників. У зв'язку з цим, багато фахів- 
ців вказують на можливість виробництва усіх перерахованих видів м'ясної продукції в Україні і навіть їх експорту: порівняно м'який клімат, наявність вільних трудових ресурсів, відповідної кормової бази.

3 досвіду розвинених європейських країн, ринок нетрадиційних видів м'яса птиці можна оцінити в кількості приблизно 0,5-0,8 \% від валового виробництва м'яса птиці, що становить для України 3,5-5,5 тис. т в живій масі. Близько третини з цієї кількості (1,2 - 1,8 тис. т) може становити м'ясо голубів. При середній живій масі голубів при забої на м'ясо 700 г, для отримання даної кількості м'яса потрібно утримувати і відгодовувати в рік 1,7-2,6 млн. голів голубів м'ясних порід. Отримання даної кількості голуб'ятини і відтворення можуть забезпечити 113-117 тис. гол. голубів батьківських стад. Для утримання такої кількості голубів потрібно 35-40 тис. м² корисної площі пташників або 70-100 пташників. Перспектива цілком реальна для нашої країни, якщо врахувати що тільки для курей в Україні експлуатується більше 2000 пташників, і більше 1300 пташників для вирощування бройлерів. До цього можна додати наявність в країні близько 6 млн. присадибних господарств.

У країнах традиційно розвиненого м'ясного голубівництва (США, Франція, Італія) - це одна з найбільш рентабельних підгалузей птахівництва.

Висновок. Перспектива розвитку м'ясного голубівництва в Україні дуже суттєва. Маючи майже безграничні природні ресурси для цієї галузі, м'ясне голубівництва може і повинно реалізувати свій потенціал не тільки на внутрішньому але й на зовнішньому ринках, дозволить покращити раціон українців i, як наслідок, внесе свою долю у процес оздоровлення нації. Тобто розвиток м'ясного голубівництва в Україні має економічне та соціальне підгрунтя.

\section{Бібліографічний список}

1. Болтянський Б. В. Розведення перепелів - родинний бізнес / Б. В. Болтянський, Л. О. Болтянська, А. С. Комар // Тваринництво сьогодні. 2018. - № 5. - С. 37-43.

2. Ladyka V. I., Sklyarenko Y. I., Pavlenko Y. M. Characteristics of the genetic structure of lebedinian breed bulls for the kappa-casein gene (CSN3) // Animal Breeding and Genetics. - 2018. - T. 56. - C. 157-161.

3. Котелевич В. А. Роль органічного виробництва у формуванні якості і безпеки харчової продукції у Житомирському регіоні / В. А. Котелевич // Органічне виробництво і продовольча безпека : зб. доп. V Міжнар. наук.-практ. конф. Житомир : ЖНАЕУ, 2017. - С. 169-172.

4. Акімов О. В. Оцінка відгодівельних якостей свиней з позиції оптимальної взаємодії їх генотипів та специфіки середовища / О. В. Акімов // Вісник аграрної науки Причорномор'я. - 2015. - №. 2 (2). - С. 87-90.

5. Церенюк О. М. Перспективи розведення свиней української м'ясної породи в Україні / О. М. Церенюк // Інноваційні розробки в аграрній сфері : матеріали. міжнар. наук.-практ. конф. «Молодь і технічний прогрес в АПВ» (12-13 квітня 2018 р., м. Харків) / Харків. нац. техн. ун-т сіл. госп-ва. - Харків, 2018. - Т. 2. C. 86 .

6. Концепція органічного виробництва сільськогосподарської продукції в Україні / ННЦ Інститут землеробства ННАН. - 2015. - 42 с.

7. Наукові основи виробництва органічної продукції в Україні : монографія / за ред. Я. М. Гадзала, В. Ф. Камінського. - Київ : Аграрна наука, 2016. - 595 с.

8. Линец А. А. Совершенствование технологии переработки птицы / Линец А. А., Касьянов Г. И., Авдеева Т. В. - Краснодар: КНИИХП, 2006. -152 с. 
9. Винюков А. А. Декоративное и мясное голубеводство / А. А. Винюков, А. А. Винюков. - М., АСТ, 2011. -320 с.

10. Винюков А. А. Полный справочник по домашнему голубеводству / А. А. Винюков, А. А. Винюков. - М. Астрель, 2012. - 320 с.

11. Гладкова М. Г. Возможность использования нетрадиционного мясного сырья при производстве комбинированных продуктов питания геродиетического назначения / Гладкова М. Г., Запорожский А. А. // Инновационные технологии и безопасность пищевых продуктов : сб. материалов междунар. науч.-практ. конф., 18 мая 2018 г. - Краснодар: Изд. КубГТУ, Экоинвест, 2018. - С. 238.

12. Свиридова А. А. Особенности динамики трансфераз сыворотки крови голубей различных пород / Свиридова А. А., Жулев Н. А., Пудовкин Н. А. // Аграрная наука - сельскому хозяйству: сборник материалов [XIII Междунар. науч.практ. конф. (15-16 февраля 2018 г.)]. - Барнаул : РИО Алтайского ГАУ, 2018. Кн. 2. - С. 430.

13. Ye M., Xu M., Chen C., He Y., Ding M., Ding X., et al. Expression analyses of candidate genes related to meat quality traits in squabs from two breeds of meat type pigeon //Journal of animal physiology and animal nutrition. - 2018. - T. 102. - №. 3. - C. 727-735.

14. Mao H. G., Cao H. Y., Liu H. H., Dong X. Y., Xu N. Y., Z. Z. Yin Association of ADSL gene polymorphisms with meat quality and carcass traits in domestic pigeons (Columba livia) // British poultry sci. - 2018. - T. 59. - №. 5. C. 604-607.

15. Винюков А. А. В мире людей и голубей / А. А. Винюков. - Вінниця, ТОВ «Нілан-ЛТД», 2016. - 148 с.

16. Виробництво м'яса голубів. Технологічний процес. Основні параметри : СОУ 01.24-37-536:2006. - Київ :Мінагрополітики України, 2006. - 18 с.

17. Аралов А. В. Продуктивность и мясные качества голубей породы кинг при вольерном содержании / А. В. Аралов // Известия Тульского гос. ун-та. Естественные науки. - 2018. - №1. - С. 78-88.

18. Столяр Т. А., Аралов А. В. Домашние голуби. Практические советы по содержанию, разведению, кормлению и профилактике заболеваний. Сергиев Посад : ВНИТИП, 2004. - 384 с.

19. Фісінін В. Якість харчових яєць і здорове харчування / В. Фісінін, А. Штеле, Г. Ерастов // Птахівництво. - 2008. - № 2. - С. 2-6.

20. Войтенко С. Л. Сучасний генофонд курей України / С. Л. Войтенко, О. О. Васильєва // Вісник Полтавської державної аграрної академії. - 2018. - №. 3. - C. 115-121.

21. Варченко О. М. Організаційно-економічні засади формування попиту на ринку м'ясної продукції в Україні / О. М. Варченко, I. В. Артімонова, Н. Г. Копитець // Сталий розвиток економіки. - 2018. - № 2. - С.166-172.

22. Минів Р. М. Особливості розвитку м'ясного птахівництва в сільськогосподарських підприємствах України / Р. М. Минів, I. В. Вороний // Науковий вісник Львівського національного університету ветеринарної медицини та біотехнологій імені С. 3. Гжицького. - 2017. - Т. 19, №. 76. - С. 77-81. 


\section{References}

1. Boltyans'kyy, B. V., \& Boltyans'ka, L. O., Komar, A. S. (2018). Rozvedennya perepeliv - rodynnyy biznes [Breeding quail - family business]. Tvarynnytstvo s`ohodni-Livestock Today, 5, 37-43 [in Ukrainian].

2. Ladyka, V. I., \& Sklyarenko, Y. I., Pavlenko, Y. M. (2018). Characteristics of the genetic structure of lebedinian breed bulls for the kappa-casein gene (CSN3). Animal Breeding and Genetics, 56, 157-161.

3. Kotelevych, V. A. (2017). Rol orhanichnoho vyrobnytstva u formuvanni yakosti i bezpeky kharchovoyi produktsiyi u Zhytomyrs komu rehioni [The role of organic production in the formation of quality and safety of food products in the Zhytomyr region]. Orhanichne vyrobnytstvo i prodovol cha bezpeka - Organic production and food safety. Zhytomyr, 169-172 [in Ukrainian].

4. Akimov, O. V. (2015). Otsinka vidhodivel`nykh yakostey svyney z pozytsiyi optymal`noyi vzayemodiyi yikh henotypiv ta spetsyfiky seredovyshcha [Estimation of fattening qualities of pigs from the standpoint of optimal interaction of their genotypes and specificity of the environment]. Visnyk ahrarnoyi nauky Prychornomor'ya Bulletin of Agrarian Science of the Black Sea Region. 2 (2), 87-90 [in Ukrainian].

5. Tserenyuk, O. M. (2018). Perspektyvy rozvedennya svyney ukrayins`koyi m`yasnoyi porody v Ukrayini [Prospects of breeding of pigs of Ukrainian meat breed in Ukraine]. Innovatsiyni rozrobky $v$ ahrarniy sferi - Innovative developments in the agrarian sphere. Kharkiv, 2, 86 [in Ukrainian].

6. Kontseptsiya orhanichnoho vyrobnytstva sil`s `kohospodars`koyi produktsiyi v Ukrayini [Concept of organic production of agricultural products in Ukraine] (2015), 42 [in Ukrainian].

7. Hadzalo YA. M., Zaryshnyak A. S., Kamins'kyy V. F., Dehodyuk E. H., Sayko V. F., Kostenko O. I. et al (2016). Naukovi osnovy vyrobnytstva orhanichnoyi produktsiyi $v$ Ukrayini: monohrafiya [Scientific basis of production of organic products in Ukraine] [in Ukrainian].

8. Linets, A. A., \& Kas'yanov G. I., Avdeyeva T. V. (2006). Sovershenstvovaniye tekhnologii pererabotki ptitsy [Improvement of poultry processing technology]. Krasnodar: KNIIKHP [in Russian].

9. Vinyukov, A. A., \& Vinyukov, A. A. (2011). Dekorativnoye $i$ myasnoye golubevodstvo [Decorative and meat pigeon breeding]. Moscjw: AST [in Russian].

10. Vinyukov A. A., \& Vinyukov A. A., (2012). Polnyy spravochnik po domashnemu golubevodstvu [Complete reference book on domestic pigeon breeding]. Moscow: Astrel' [in Russian].

11. Gladkova, M. G., \& Zaporozhskiy, A. A., (2018). Vozmozhnost' ispol'zovaniya netraditsionnogo myasnogo syr'ya pri proizvodstve kombinirovannykh produktov pitaniya gerodiyeticheskogo naznacheniya [The possibility of using unconventional raw meat in the production of combined food products for purposes of gerodietics]. Innovatsionnyye tekhnologii i bezopasnost' pishchevykh produktov - Innovative technologies and food safety. - Collection of materials of the international scientific-practical conference, May 18, 2018. Krasnodar. p. 238 [in Russian].

12. Sviridova A. A., \& Zhulev N. A., Pudovkin N. A. (2018). Osobennosti dinamiki transferaz syvorotki krovi golubey razlichnykh porod - Peculiarities of the dynamics of serum transferases in pigeons of various breeds. Agrarnaya nauka sel'skomu khozyaystvu - Agrarian science to agriculture: collection of materials: XIII International Scientific and Practical Conference (February 15-16, 2018). Barnaul. p. 430 [in Russian]. 
13. Ye M., Xu M., Chen C., He Y., Ding M., Ding X., et al. (2018). Expression analyses of candidate genes related to meat quality traits in squabs from two breeds of meat type pigeon // J. of animal physiology and animal nutrition. 102, 3, 727-735.

14. Mao H. G., Cao H. Y., Liu H. H., Dong X. Y., Xu N. Y., Z. Z. Yin (2018). Association of ADSL gene polymorphisms with meat quality and carcass traits in domestic pigeons (Columba livia). British poultry science. 59, 5, 604-607.

15. Vynyukov, A. A. (2016). V myre lyudey y holubey [In the World of Humans and Pigeons]. Vinnytsya, TOV «Nilan-LTD» [in Russian].

16. Vyrobnytstvo m`yasa holubiv. Tekhnolohichnyy protses. Osnovni parametry: Manufacture of pigeon meat. Technological process. Basic parameters., (2006). SOU 01.24-37-536:2006. Kyiv. [in Ukrainian].

17. Aralov, A. V. (2018). Produktivnost' i m'yasne kachestva golubey porody king pri vol'yernom soderzhanii [Productiveness and quality of pigeons of the king king at captive content]. Izvestiya Tul'skogo GU. Yestestvennyye nauki - Bulletin of Tula State University. Natural sci., 1, 78-88 [in Russian].

18. Stolyar, T. A., \& Aralov, A. V. (2004). Domashniy holuby. Domashniye golubi. Prakticheskiye sovety po soderzhaniyu, razvedeniyu, kormleniyu i profilaktike zabolevaniy [Domestic pigeons. Practical tips for keeping, breeding, feeding and preventing diseases]. Sergiev Posad: VNITIP [in Russian].

19. Fisinin, V., \& Shtele, A., Erastov, H. (2008). Yakist` kharchovykh yayets`i zdorove kharchuvannya [Quality of food eggs and healthy eating]. Ptakhivnytstvo Poultry breeding. 2, 2-6 [in Ukrainian].

20. Voytenko, S. L., \& Vasyl yeva, O. O., (2018). Suchasnyy henofond kurey Ukrayiny [Modern gene pool of chickens in Ukraine]. Visnyk Poltavs koyi derzhavnoyi ahrarnoyi akademiyi - Bulletin of the Poltava State Agrarian Academy, 3, 115-121 [in Ukrainian].

21. Varchenko, O. M., \& Artimonova, I. V., Kopytets` N. H. (2018). Orhanizatsiyno-ekonomichni zasady formuvannya popytu na rynku m'yasnoyi produktsiyi $\mathrm{v}$ Ukrayini [Organizational and Economic Principles of Demand Formation in the Market of Meat Products in Ukraine]. Stalyy rozvytok ekonomiky - Sustainable development of the economy, 2,166-172 [in Ukrainian].

22. Myniv, R. M., \& Voronyy, I. V. (2017). Osoblyvosti rozvytku m`yasnoho ptakhivnytstva $\mathrm{v}$ sil`s`kohospodars`kykh pidpryyemstvakh Ukrayiny [Peculiarities of Development of Poultry Farming in Agricultural Enterprises of Ukraine]. Naukovyy visnyk L'vivs`koho natsional'noho universytetu veterynarnoyi medytsyny ta biotekhnolohiy im. SZ Gzhyts koho - Scientific Bulletin of the Lviv National University of Veterinary Medicine and Biotechnologies named after S. Z. Gzhytsky. 19, 76, 77-81 [in Ukrainian].

\section{СОВРЕМЕННОЕ СОСТОЯНИЕ И ПЕРСПЕКТИВЫ РАЗВИТИЯ МЯСНОГО ГОЛУБЕВОДСТВА В УКРАИНЕ}

Винюков А. А., Институт животноводства НААН

Винюков А. А., Донецкая государственная сельскохозяйственная опытная станциия НААН

В статье рассмотрены вопросы определения перспектив развития такого нишевого сектора агробизнеса, как мясное голубеводство. Было проведено литературный и патентный поиск с целью установления состояния отрасли мясного голубеводства в Украине. Изучено зарубежный опыт в области мясного птицеводства. Определено, что во многих странах мира промышленное голубеводство очень развито. На больших голубиных фермах США и государственных фермах 
Венгрии процессы кормления, поения, уборки помещений механизированные, освоено искусственное вскармливание птенщов. Сначала для селекиионной работы Венгерское общество голубеводов закупило племенное поголовье во Франции, а также использовало свои национальные породы крупных голубей. Затем в США были приобретены аутентичные птицы породы Тексан, и в настоящее время ведется планомерная работа по созданию гибридов большой живой массы, плодотворных, неприхотливых и устойчивых к заболеваниям.

Рассмотрены отдельные элементы технологии производства продукции голубеводства. Отмечено определенные особенности отрасли. Спаривание у голубей начинается с пятимесячного возраста. Молодняк голубей мясных пород, выведен в марте и оставлен на племя, в сентябре-октябре уже дает приплод. В среднем в одной пары мясных голубей при интенсивной технологии за год может быть 9-10 кладок (18 птенцов). Итак, ожидаемый выход товарной продукиии составит 8,5-9 кг в течение года. Производство товарной продукции, как правило, неравномерное: 60-65 \% мяса получают в весенне-летний период, 20-30\% осенью и 10-15 \% зимой. Производство может быть рентабельным, если вывод молодняка в хозяйстве составляет не менее $75 \%$. В первые годы жизни репродуктивная способность у голубей постепенно повышается, затем равномерно снижается и на 6-7-м году резко падает. Вообще же голуби живут в среднем 1520 лет, а размножаются в течение 10-12 лет.

Голуби моногамны, держатся стаями и ведут дневной образ жизни. Насиживают яйца обе птиџы: самеи обычно с 10 до 16 часов, самка все остальное время. Масса яии у голубей колеблется от 17 до 27 г. Температура насиживания яии составляет 36,1-40,7 ${ }^{\circ}$ C. Продолжительность насиживания у домашнего голубя в среднем 17-19 суток, но в холодном помещении увеличивается до 20-22 дней.

Ключевые слова: птичеводство, голуби, продуктивность, мясные породы, диетическое мясо, рынок продукиии.

\section{CURRENT STATE AND DEVELOPMENT PROSPECTS OF MEAT PIGEON BREEDING IN UKRAINE}

Vinyukov O. A., Institute of Animal Science of the NAAS.

Vinyukov A. A., Donetsk State Agricultural Experimental Station of the NAAS.

The article highlights the meat pigeon breeding prospects determination as a new agribusiness sector. A literature and patent search was conducted for the state of the meat pigeon breeding industry in Ukraine established. The foreign experience in the field of meat poultry was studied. In many countries of the world the pigeon meat breeding industrial is very developed. On large pigeon farms in the United States and on state farms in Hungary the feeding, watering and housekeeping processes are mechanized, the nestling artificial feeding has been mastered. First of all, for breeding work, the Hungarian pigeon breeders' society purchased the breeding stock in France, and also used its national large pigeon's breeds. Then, authentic Texan birds had been purchased in the United States, and a systematic work on high bodyweight hybrids creation carry out now for high productivity, unpretentious and disease-resistant breeds obtaining.

The some elements of the technology of pigeon production were considered. A certain features of the industry were marked. Mating pigeons starts from five months of age. The young meat pigeons were born in March and have been left for breeding, in September-October already give offspring. An average of one pair of meat pigeons at intensive technology during the year can be obtained 9-10 clutches (18 nestlings). So, 
the expected yield of marketable products will be 8.5-9 $\mathrm{kg}$ during the year. The production of marketable products, as a rule, is uneven: 60-65\% of meat is produced in the spring-summer period, 20-30 \% - in autumn and 10-15\% - in the winter. Production can be profitable if the output in young stock on the farm is not less than 75\%. In the first years of life, reproductive ability in pigeons gradually increased, then evenly reduced and 6-7-year drops sharply. In general, pigeons live an average of 15-20 years, and give offspring for 10-12 years.

Pigeons are monogamous, keep in flocks and lead a daily life. Both birds hatch eggs: the male is usually from 10 to 16 hours, the female - the rest of the time. The mass of eggs in pigeons ranges from 17 to $27 \mathrm{~g}$. The egg incubation temperature is 36.1$40.7^{\circ} \mathrm{C}$. The duration of hatching of the domestic pigeon is on average 17-19 days, but in a cold room it increases to 20-22 days.

Key words: poultry breeding, pigeons, productivity, meat breeds, dietary meat, product market.

DOI 10.32900/2312-8402-2018-120-39-46

УДК 636.085.52:[633.15+633.17]

\title{
ПЕРЕТРАВНІСТЬ ПОЖИВНИХ РЕЧОВИН СИЛОСІВ СУМІСНИХ ПОСІВІВ КУКУРУДЗИ ТА СОРГО
}

\author{
Дроздова О. В., \\ Дроздов С. С., К. с.-Г. Н., с. Н. с, \\ Василевський М. В., к. б. Н., с. н. с., \\ Єлецька Т. О., к. б. н., \\ Інститут тваринництва НААН \\ Халін С. Ф., к. с.-Г. н., \\ Луганський національний аграрний університет
}

У статті наведено результати досліджень хімічного складу та поживної цінності силосів, приготовлених із сумісних посівів гібридів кукурудзи з різним ФАО та сорго. В середньому силоси, заготовлені з зеленої маси кукурудзи та сорго, містили, у перерахунку на абсолютно суху речовину, менше на 1,03\% абсолютних протеїну, 0,31 \% жиру та більше на 7,42 \% клітковини. Відмінності у хімічному складі спричинили зниження поживної иінності силосів, виготовлених із зеленої маси сумісних посівів кукурудзи та сорго, в середньому по 12 варіантах, з 10,38 до 9,23 МДж в 1 кг сухої речовини.

Визначено гібриди кукурудзи з оптимальним ФАО, використання яких у сумісних посівах з сорго, забезпечать отримання силосу, котрий за показниками якості не поступатиметься кукурудзяному, що, в свою чергу, сприятиме забезпеченню сталої кормової бази для високопродуктивного тваринництва.

Встановлено, щзо при рачіональному підборі гібриду кукурудзи, зниження вмісту протеїну, порівняно з кукурудзяним силосом, практично не відбувається. Так, на кращих варіантах різниия за вмістом сирого протеїну становила лише 0,1-0,2 \% у перерахунку на абсолютно-суху речовину. Щодо вмісту ДОЕ в дослідних силосах, то правильний підбір гібридів кукурудзи дає змогу зменшити різнищю, порівняно з кукурудзяними силосом, з 1,1 - 1,6 до 0,5 - 0,7 МДж/ кг сухої речовини.

Як результат проведених досліджень, в середньому по 12 варіантах, було встановлено вірогідне зниження перетравності сухої речовини $(p \leq 0,01)$, протеї- 